\title{
Distribution of aliphatic and polycyclic aromatic hydrocarbons (PAHS) in coastal sediment from the Ngoua River (Douala, Cameroon)
}

\author{
Jessie Ekoka Christelle Solange ${ }^{1}$, Ngassoum Martin Benoit ${ }^{1}$, Ze Bilo'o Philemon ${ }^{1,2}$ \\ ${ }^{1}$ Departement of Applied Chemistry and Environment Management, National School of Agro-Industrial Sciences (ENSAI), University of \\ Ngaoundere, Cameroon \\ ${ }^{2}$ Laboratory of Chemistry, Faculty of Science, University of Bamenda, Cameroon
}

Email address:

jessieekoka@yahoo.fr (J. E. C. Solange), zebiloop@yahoo.fr (Z. B. Philemon)

\section{To cite this article:}

Jessie Ekoka Christelle Solange, Ngassoum Martin Benoit, Ze Bilo'o Philemon. Distribution of Aliphatic and Polycyclic Aromatic Hydrocarbons (PAHS) in Coastal Sediment from the Ngoua River (Douala, Cameroon). International Journal of Environmental Monitoring and Analysis. Vol. 2, No. 5, 2014, pp. 272-278. doi: 10.11648/j.ijema.20140205.17

\begin{abstract}
This paper reports the identification and quantification of 15EPA-PAHs in the sediments samples collected in Ngoua River, Douala, Cameroon. PAH and $n$-alkanes were separated by using a chromatographic column, identified and quantified by using Gas Chromatography (GC/FID). The total concentration ranged from $140.42 \mu \mathrm{g} / \mathrm{g}$ to $229.47 \mu \mathrm{g} / \mathrm{g}$ dry matters during the rainy season and from $48.89 \mu \mathrm{g} / \mathrm{g}$ to $333.49 \mu \mathrm{g} / \mathrm{g}$ dry matters during the dry season. All samples showed the predominance of high Molecular Weight (HMW) PAHs due to industrial activities. At the upstream, the concentrations of PAHs were systematically lower than those found downstream indicating an influence of Nettoycam Company in the local pollution by PAHs. Principal component analysis (PCA) also showed remarkable differences of characteristics of samples collected upstream and downstream of Nettoycam Company, samples location and also of samples from rainy and dry seasons.
\end{abstract}

Keywords: Environmental Pollution, Hydrocarbons, Rivers, Sediment, Pahs

\section{Introduction}

Hydrocarbons compounds occurring are naturally and are important components of organic matter from marine coastal sediment. The composition and distribution are significantly affected by human activities, particularly in recent decades. They are an assemblage of substances coming from biogenic, diagenic, petrogenic and/or pyrogenic sources [23],[10] and have received much attention due to their ubiquitous distribution in marine and river sediments [21]. PAHs have environmental significance due to their potential toxicity to organisms. They are often hydrophobic and easily accumulated in sediment, organisms through food chains, and present a potential threat to aquatic ecosystems and even to human health [18].

Sediments are recognized as excellent sinks for pollutants such as hydrocarbons [16], and constitute an appropriate matrix for chemical analysis [12].

A pool of aliphatic diagnostic indices and more particular signatures can be used to identify biogenic terrestrial or marine or anthropogenic sources. PAHs distributions are also useful to differentiate the PAHs main sources, particularly to distinguish petrogenic from pyrogenic hydrocarbons [2].

In Douala (Cameroon) several coastal areas are suffering from the anthropogenic input due to the industrial and economic activity, such as the Ngoua River located in the industrial zone of Bassa (Douala) in the neighborhood of Nettoycam industry. This industry is specialized in treatment of hydrocarbons wastes. Many years ago, the principal economical activity of this River was fishing. But the intensification of industrial activity is responsible of the disappearance of fishes and shrimps [9]. Today the only activity of this River is wood selling and sand extraction by children especially during holydays in dry season.

A study carried out by Baok (2007) and by Rharrassin (2008) reported this river as the most polluted by microbiological and inorganic element $(\mathrm{Cu}, \mathrm{Ni}, \mathrm{Pb})$. Nevertheless the organic pollution such as hydrocarbons is never study in this area. This work provides a more complete study of the industrial pollution of this River and the first to investigate the composition, origin and distribution of aliphatic and PAHs in 
sediment in this River. The PAHs concentrations and distribution are discussed in terms of sampling location, seasonal variation, origin and sources.

\section{Materials and Methods}

\subsection{Study Areas and Sampling Sites}

Ngoua River is one of long river of Douala (Cameroon) located in the industrial zone of Bassa. This River has about 7 $\mathrm{km}$ of coast. Two series of sediment were used in the present study. The first series of four sites were taking in the dry season and the four others sites were taking in the raining season. In each sampling site, sediment were taken in eight adjacent point selected randomly, homogenized in a single sample $(1 \mathrm{~kg})$, was kept in the laboratory for analysis. Samples of surface sediments were collected at stations along the coastal areas of Ngoua River as depicted in the map of the study area (Figure-1). The sampling campaign was conducted at 4 sites during August 2010 (raining season) and February 2011 (dry season). A global positioning system (GPS) was used to pinpoint sampling locations (Table 1).The sediments were dried in the open air, crushed and sieved and $2 \mathrm{~mm}$ diameter fraction was used for further analysis. They were subsequently kept in a refrigerator at $-20^{\circ} \mathrm{C}$ prior to analysis.

Table 1. Location and characteristics of sampling sites.

\begin{tabular}{|c|c|c|c|}
\hline Names of station & Latitude & Longitude & Depth (m) \\
\hline After Nettoycam industry (N1) & $04^{\circ} 01.571^{\prime} \mathrm{N}$ & $009^{\circ} 43.560^{\prime} \mathrm{E}$ & 4 \\
\hline In the neighborhood of Nettoycam (N2) & $04^{\circ} 00.878^{\prime} \mathrm{N}$ & $009^{\circ} 44.104^{\prime} \mathrm{E}$ & 8 \\
\hline Song-Mahop (N3) & $04^{\circ} 00.557^{\prime} \mathrm{N}$ & $009^{\circ} 44.304^{\prime} \mathrm{E}$ & 5 \\
\hline Village-shell (N4) & $04^{\circ} 00.535^{\prime} \mathrm{N}$ & $009^{\circ} 44.223^{\prime} \mathrm{E}$ & 6 \\
\hline
\end{tabular}

\subsection{Sample Extraction and Cleanup}

The extraction procedure used for sediment samples is described in the literature [4]. Sediments were soxhlet extracted with $25 \mathrm{~mL}$ of methanol for $2 \mathrm{~h}$. The extract was concentrated and solvent-exchanged to hexane using a rotary evaporator. The hexane extract was subject to a 1:2 alumina/silica gel glass column for cleanup and fractionation. The column was eluted with $15 \mathrm{~mL}$ hexane and the eluted was discarded. The $n$-alkane fraction was eluted with $10 \mathrm{ml}$ of hexane, the second fraction containing the mixture of $n$-alkane and $\mathrm{PAH}$ was eluted with $10 \mathrm{ml}$ of hexane/ethyl acetate mixture $(83: 17, \mathrm{v} / \mathrm{v})$ and the third fraction containing only the PAHs was eluted with $20 \mathrm{~mL}$ of hexane/ethyl acetate mixture $(65: 35, \mathrm{v} / \mathrm{v})$.

\subsection{Analysis for Hydrocarbons Identification and Quantification}

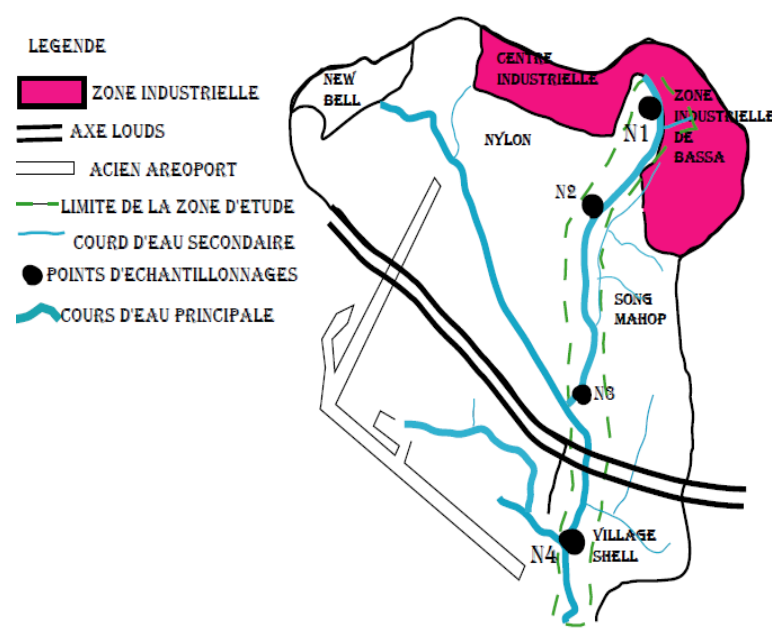

Fig 1. Samples location of sediments in Ngoua River

PAHs and $n$-alkanes concentrations were determined using the SHIMADZU GC-14B gas chromatograph (GC) equipped with a flame ionization detector (FID) and a Hewlett Packard integrator. The GC-FID was using a ZB-5 capillary column of $30 \mathrm{~m}$ length, $0.32 \mathrm{~mm}$ film thickness, and $0.25 \mu \mathrm{m}$ of internal diameter (US PATENT); Varian, Walnut Creek, CA, USA). Nitrogen (99.999\%) was used as the GC carrier gas at a constant flow of $1.0 \mathrm{ml} / \mathrm{min}^{-1}$. A microsyringe was used to inject $1-\mu \mathrm{L}$ samples into the chromatograph. The column temperature was programmed from $40^{\circ} \mathrm{C}(5 \mathrm{~min})$ at $320^{\circ} \mathrm{C}$ (45min) at $6^{0} \mathrm{Cmin}^{-1}$ and identification using standards with their Kovats Index (IK).

\section{Results and Discussions}

\subsection{N-Alkane Distribution and Sources}

Normal n-alkanes in the range $\mathrm{C}_{9}-\mathrm{C}_{28}$ was found but only $\mathrm{C}_{12}-\mathrm{C}_{28}$ was present in all samples. The total n-alkanes concentrations (TNA) ranged from $144,23{\mu g g^{-1}}^{-1}$ to 1567.21 $\mu \mathrm{gg}^{-1}$ in the rainy season and from $105.64 \mu \mathrm{g} . \mathrm{g}^{-1}$ to 2670.73 $\mu \mathrm{g} \cdot \mathrm{g}^{-1}$ in the dry season, with a highest concentration at $\mathrm{N} 2$ $\left(2670.73 \mu \mathrm{gg}^{-1}\right)$. The concentrations of all n-alkanes decreased from dry to rainy season (February to August) possibly due to the rainy period and to the consequent increase of river water flow and volume that led to n-alkanes dilution. The results of our study show the predominance of n-alkanes $\mathrm{C}_{19}-\mathrm{C}_{28}$ in the rainy season and $\mathrm{C}_{13}-\mathrm{C}_{28}$ in dry season with the predominance of $\mathrm{C}_{20}-\mathrm{C}_{28}$. This result was attributed to mixed origin of biogenic, bacteria and anthropogenic organic source inputs. For a better understanding of the principal sources of sediments contamination the determination of the carbon preference index (CPI) and the ratio of $\mathrm{n}-\mathrm{C}_{17} /$ Pristane and $\mathrm{n}-\mathrm{C}_{18} /$ Phytane was calculated. The CPI (carbon preference index), a measure of biologically synthesized n-alkanes[26, 27], indicates the relative contributions of n-alkanes from natural (biogenic/terrestrial; CPI > 1) compared to anthropogenic $(\mathrm{CPI}<1)$ sources. The $(\mathrm{CPI})$ was calculated according to [28] using the same odd-carbon and even-carbon number n-alkane 
concentrations in the respective samples as follows:

$$
\mathrm{CPI}=(\mathrm{C} 23+\mathrm{C} 25+\mathrm{C} 27+\mathrm{C} 29+\mathrm{C} 31) /(\mathrm{C} 24+\mathrm{C} 26+\mathrm{C} 28+\mathrm{C} 30)
$$

Values of CPI ranged from 0.07-1.48 for the entire stations, with maximum value (1.48), indicating a relatively higher proportion of n-alkanes from anthropogenic (mostly petroleum) sources

\subsection{PAHs Distribution and Sources}

\subsubsection{PAHs Distribution}

The total concentration ranged from $140.42 \mu \mathrm{g} \cdot \mathrm{g}^{-1}$ to $229.47 \mu \mathrm{g} . \mathrm{g}^{-1}$ dry weights during the rainy season and from $48.89 \mu \mathrm{g} . \mathrm{g}^{-1}$ to $333.49 \mu \mathrm{g} . \mathrm{g}^{-1}$ dry weight during the dry season, with a highest concentration at N2 $\left(333.49 \mu \mathrm{g} \cdot \mathrm{g}^{-1}\right)$. ). Sites $\mathrm{N} 2$ and $\mathrm{N} 3$ were both located at the Nettoycam industry, present the highest level of PAHs during all season (Figure 2). This concentration is probably due to the recent deposition and accumulation of PAHs in the sediments. Compared to the low PAHs concentrations in sediment at site N1 and N3 a high level of PAHs was found at the site N2 and N4, which can be attributed to recent PAHs input around the area.

In the 16 PAHs repertory by European and American lists (U.S. Environmental Protection Agency, EPA), for their

a)

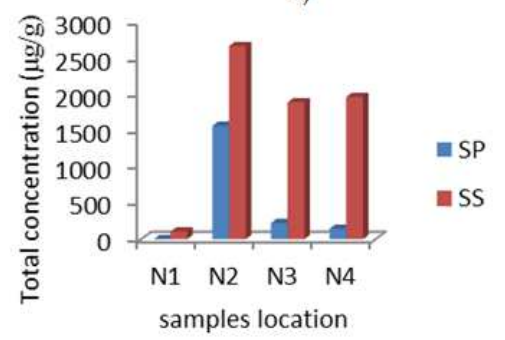

cancerogenicity and toxicity, 15 PAHs were found to be present in this study. For the individual distribution, the PAHs with high molecular weight are the predominate in the two season (raining and dry season).The PAHs distribution was mostly dominated by high molecular weight PAHs (4-, 5- and 6-rings) such as Fluoranthene, pyrene, Benzo[a]anthracene, Chrysene, Benzo[a]pyrene, Indeno[1,2,3-cd]pyrene, Benzo[ghi]perylene with the high concentration for Benzo[ghi]perylene $\left(101,02{\mu g g^{-1}}^{-1}\right)$.

The higher concentration of Benzo[ghi]perylene (101,02 $\left.\mu \mathrm{gg}^{-1}\right)$ is probably due the presence of the 6 rings in the structure. In the literature the biodegradability and bio-disponibility are function of the number of ring [23]. In this case, the PAHs with high molecular weight are not more hydrophilic like the 2-3 rings and the dissolution in the water is very difficult. This reason can be explain the concentration of this type of PAHs in the sediment.

The presence of the 2- and 3-ring at site N4 in the dry and rainy season is probably due to the presence of industrial activity such as petrol station located before of the site N4. These low PAHs concentration is because 2-and 3-rings PAHs are not strongly adsorb onto the surface of suspend and fine particles and they also have easily dissolution in water.

b)

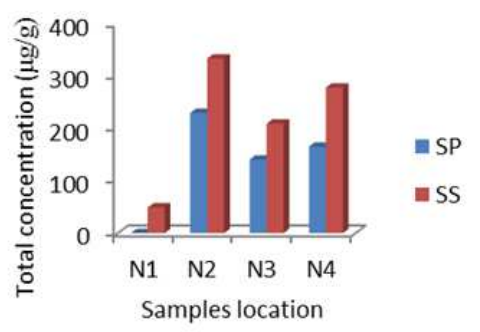

Fig 2. Total concentration of n-alkanes (a) and PAHs (b) in the Ngoua River sediment; SS: Dry season, SP: rainy season.

For the individual PAHs the highest concentration is from Dibenzo[agh]pyrelene $\left(101,02 \mu \mathrm{gg}^{-1}\right)$ at site N4 in dry season and the lowest concentration is from Acenaphtene $\left(2,25 \mu \mathrm{gg}^{-1}\right)$ in dry season. This result demonstrated that the HMW because of the composition have easily accumulation in the some matrix such as sediments, sands, suspend particles. Beyond this, some authors have also investigated the importance of high molecular weight PAHs [1],[15], [20] in many rivers likes Ushuaia Bay, Blanca Bay, and the Cienfuegos Bay (Cuba) (Table 2).

Table 2. Total concentration of PAHs in sediments of some rivers in the words.

\begin{tabular}{|c|c|c|c|c|}
\hline Location & $\mathbf{N a}$ & 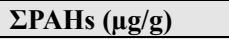 & $\mathrm{UCM}(\mu \mathrm{g} / \mathrm{g})$ & Reference \\
\hline Ngoua River (Cameroun) & 15 & $48.98-333.49$ & $132.21-2763,23$ & This study \\
\hline Bahía Ushuaia, Patagonia & 10 & $\mathrm{Nd}-0.360$ & $4-1050$ & Marta et al. (2012) \\
\hline Bahía Blanca Estuary & 24 & $0.015-0.010$ & & Arias et al. (2010) \\
\hline Marseille Bay (France) & 11 & $0.034-1.826$ & & Asia et al. (2009) \\
\hline Daya Bay, South China & 14 & $0.0425-0.156$ & & Yan et al. (2009) \\
\hline Abu Qir Bay, Egypt & 20 & $<$ MDL- 2.660 & & Khairy et al. (2009) \\
\hline Gulf of Aden, Yemen & 17 & $0.022-0.604$ & & Mostafa et al. (2009) \\
\hline Dialo Estuary River China & 16 & $0.272-1.606$ & & Bin et al. (2009) \\
\hline Bahía Nueva, Patagonia & 12 & $0.010-7.690$ & $0.01-8.53$ & Massara et al. (2008) \\
\hline Eastern Aegean Sea, Izmir Bay & 16 & $0.0025-0.113$ & & Darilmaz and Kucuksezgin (2007) \\
\hline Bonny River (Nigeria) & 24 & $2.13-16.72(\mathrm{mg} / \mathrm{kg})$ & & Bassey et al. (2012) \\
\hline Patagonia Coast & 86 & $0.010-7.690$ & Nd-1195 & Commendatore and Esteves (2007) \\
\hline Pearl River Estuary & 9 & $0.189-0.6367$ & & Luo et al. (2006) \\
\hline
\end{tabular}

Na: Number of PAH compounds analyzed in each study.

$\mathrm{Nd}$ : not detected by the methods. 
According to Dzalla (2002) the pollution of this river especially by PAHs must be taken seriously otherwise the population going to be affected. Seven of the examined PAHs (i.e., ., Benzo[a]anthracene, Benzo[b]fluoranthene, Benzo[k]fluoranthene,

Benzo[a]pyrene, Indeno[1,2,3-cd]pyrene, Dibenzo[ah]anthracene, and Benzo[ghi]perylene), which are known as carcinogens, were found in Ngoua River and represent 54 and $82 \%$ of the total concentration. This result can explain the disappearance of fishes and shrimps which represent the main revenue of the population of that area.

\subsubsection{PAHs Sources}

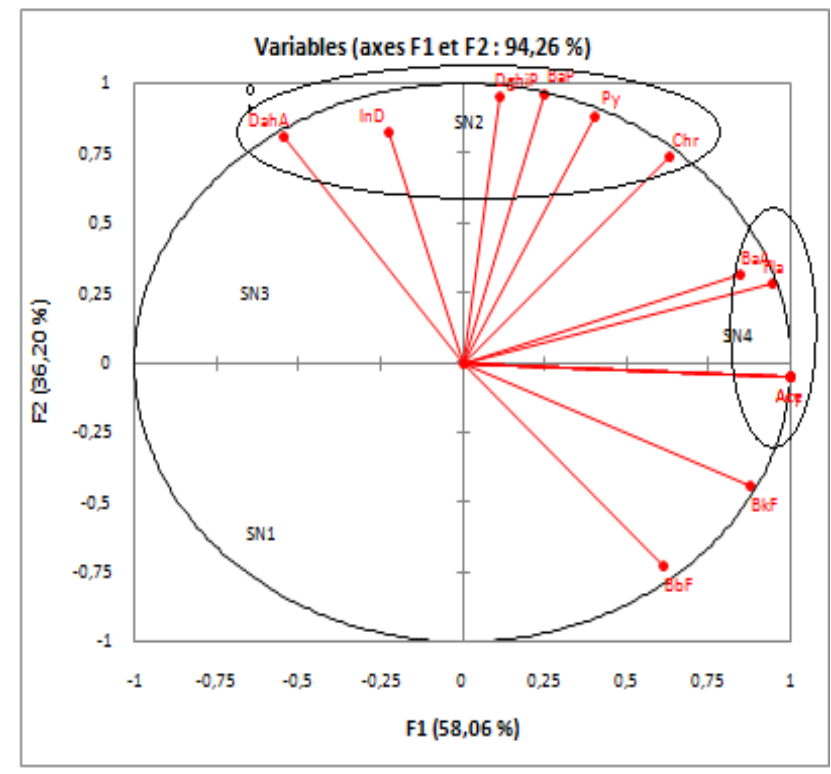

a) Ngoua dry season

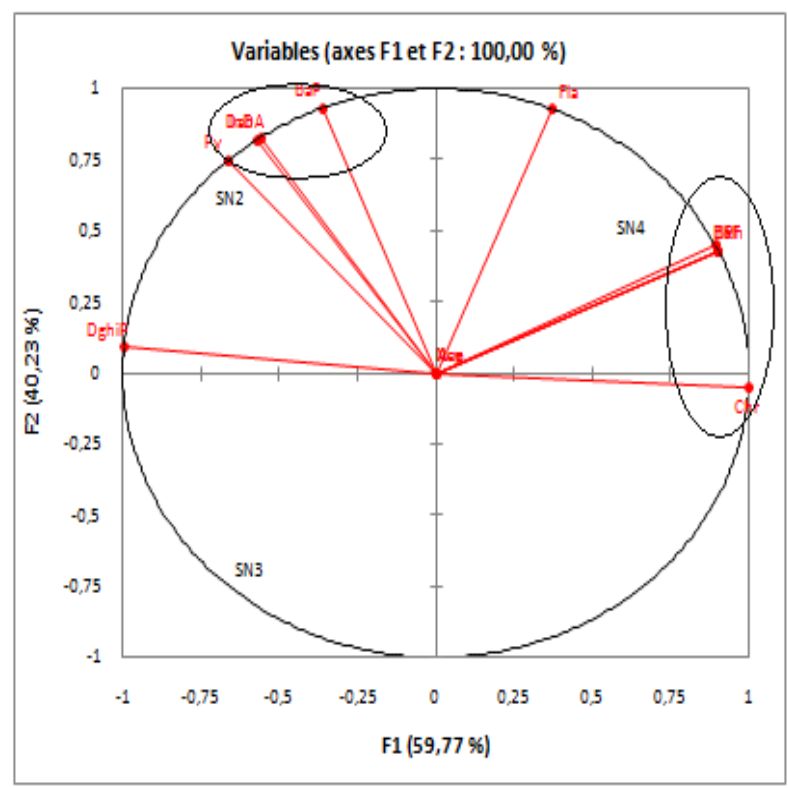

b) Ngoua rainy season.

Fig 3. PCA loading plot sediment from the Ngoua River,
Several molecular ratios of selected PAH compounds, such as the abundance ratio of 2-3-ring hydrocarbons to 4-6-ring hydrocarbons (LMW/HMW), Phen/Ant, Fl/Pyr, Fl/(Fl + Pyr), $\mathrm{InP} /(\mathrm{InP}+\mathrm{BgP})$, have been developed to aid in the interpretation of $\mathrm{PAH}$ compositions and in their possible sources (Doong and Lin, 2004). A Fl/Fl + Pyr ratio $<0.40$ indicates petroleum, $0.40-0.50$ indicates petroleum combustion, and $>0.50$ indicates the combustion of coal, grasses and wood (Doong and Lin, 2004). Value of Fl/Fl + Pyr $(0.2)<0.40$ confirm petroleum pollution. PCA is a statistical tool that resets large amounts of data and facilitates visualization of similarities and differences between data sets [11]. In this research, PCA was used to better understand of PAHs sources in the Ngoua River and seasonal variation of concentration. PCA loading plots for sediment contamination and seasonal variation are shown in Figure 2. The two principal group of compounds was concentrated in site N2 and N4, which the mean concentration of N2. This group was constituted of PAHs (i.e., Benzo[a]anthracene, Benzo[b]fluoranthene, Benzo[k]fluoranthene, Benzo[a]pyrene, Dibenzo[ah]anthracene, Benzo[ghi]perylene), which are known as carcinogens.

This demonstrates that sediments contaminants from the Ngoua River Estuary are a mixture of petrogenic (3-ring) and pyrolytic-derived (4- and 5-ring) PAHs. The high loading of site N2 indicates that the Nettoycam industry can be the main source of PAHs in sediment for the Ngoua River Estuary. Therefore, negative toxic effects exist for the Ngoua River, and they may be very significant.

\section{Conclusion}

This study has provided important data on parent PAHs levels in sediments of the Ngoua River, which is located in the industrial area in the neighborhood of the Nettoycam industry of Cameroon. The PAHs composition in the four sites examined was comprised mainly of 4- and 5-ring PAHs. This indicates a relatively recent local source and was attributed to the petrogenic source of PAHs. The PCA show the relation of sites location, sources and seasonal variation of this contamination. This result demonstrates that sediments were contaminated and this contamination was probability due to the Nettoycam industry. But to confirm this assessment, the samples most be collected inside the industry.

\section{Acknowledgment}

This study was supported by the National School of Agro-Industrial Sciences (ENSAI), University of Ngaoundere, Cameroun and the Laboratory of Active Substances and Pollution (LASP) of ENSAI. 
Table 3. Concentration of $n$-alkanes in sediments $(\mu \mathrm{g} / \mathrm{g}$ ) from $\mathrm{Ngoua}$ River.

\begin{tabular}{|c|c|c|c|c|c|c|c|c|}
\hline \multirow{3}{*}{ Compounds } & \multicolumn{8}{|c|}{ Ngoua sediments. } \\
\hline & \multicolumn{2}{|l|}{ N1 } & \multicolumn{2}{|l|}{ N2 } & \multicolumn{2}{|l|}{ N3 } & \multicolumn{2}{|l|}{ N4 } \\
\hline & $\mathrm{Rn}$ & Dry & $\mathrm{Rn}$ & Dry & $\mathrm{Rn}$ & Dry & $\mathrm{Rn}$ & Dry \\
\hline Nonane (C9) & nd & nd & nd & nd & nd & nd & nd & nd \\
\hline Decane (C10) & nd & nd & nd & nd & nd & nd & nd & nd \\
\hline Undecane (C11) & nd & nd & nd & nd & nd & nd & nd & nd \\
\hline Dodecane (C12) & nd & nd & nd & 11.46 & nd & 9.25 & nd & 10.45 \\
\hline Tridecane (C13) & nd & 7.65 & nd & 18.56 & nd & 10.34 & nd & 11.96 \\
\hline Tétradecane (C14) & nd & 8.72 & nd & 23.67 & nd & 15.13 & nd & 15.51 \\
\hline Pentadecane (15) & nd & 6.91 & nd & 12.93 & nd & 10.38 & 0.02 & 12.21 \\
\hline Hexadecane (C16) & nd & nd & nd & 19.52 & nd & 16.52 & 0.87 & 14.98 \\
\hline Heptadecane (C17) & nd & 6.74 & nd & 13.23 & 4.09 & 9.05 & 4.48 & 10.67 \\
\hline Pristane & nd & 4.07 & nd & 12.67 & 2.03 & 11.67 & 1.67 & 9.89 \\
\hline Octadecane (C18) & nd & nd & nd & 14.03 & 8.23 & 12.23 & 9.74 & 9.67 \\
\hline Phytane & nd & nd & nd & 16.89 & 9.56 & 14.33 & 3.67 & 11.67 \\
\hline C18/Phystane & nd & nd & nd & 0.83 & 0.86 & 0.85 & 2.65 & 0.82 \\
\hline Nanodecane (C19) & nd & 6.04 & 0.99 & 37.64 & nd & 12.43 & 2.44 & 21.21 \\
\hline Eicosane (C20) & nd & nd & 45.67 & 39.01 & 13.43 & 20.67 & 22.63 & 24.42 \\
\hline Heneicosane (C21) & nd & nd & 1.94 & 13.36 & nd & 9.94 & nd & 9.31 \\
\hline Docosane (C22) & nd & nd & 3.61 & 14.85 & nd & 10.62 & 4.62 & 10.28 \\
\hline Tricosane (C23) & nd & nd & 1.24 & 16.32 & nd & 10.23 & 4.89 & 10.58 \\
\hline Tetracosane (C24) & nd & nd & 462 & 25.05 & 9.64 & 21.56 & 6.72 & 14.56 \\
\hline Pentacosane(C25) & nd & nd & 6.38 & 41.97 & 8.27 & 10.34 & 9.11 & 14.29 \\
\hline Hexacosane (C26) & nd & 6.71 & 8.67 & 10.94 & 9.75 & 13.78 & 12.12 & 9.67 \\
\hline Heptacosane (C27) & nd & 8.67 & 18.94 & 11.35 & 9.91 & 10.56 & 10.61 & 12,38 \\
\hline Octocosane (C28) & nd & 6.12 & 9.32 & 10.88 & 8.56 & 17.73 & 7.73 & 21.91 \\
\hline$\Sigma$ of n-alkanes & nd & 61.63 & 101.38 & 363.33 & 83.47 & 246.76 & 101.32 & 255.62 \\
\hline UCM & nd & 105.64 & 1567.21 & 2670.73 & 223.34 & 1892.62 & 144.23 & 1967.65 \\
\hline
\end{tabular}

Rn: Rainy season; Dry: Dry season; N: Ngoua sediments ; Nd : no detected

LMW / HMW, low molecular weight / high molecular weight; UCM: Unresolved Complex Mixture

Table 4. Concentration of PAHs in sediments $(\mu \mathrm{g} / \mathrm{g})$ from Ngoua River.

\begin{tabular}{|c|c|c|c|c|c|c|c|c|}
\hline \multirow{3}{*}{ Compounds } & \multicolumn{8}{|c|}{ Ngoua sediments } \\
\hline & \multicolumn{2}{|l|}{ N1 } & \multicolumn{2}{|l|}{$\mathbf{N 2}$} & \multicolumn{2}{|l|}{ N3 } & \multicolumn{2}{|l|}{ N4 } \\
\hline & $\mathbf{R n}$ & Dry & $\mathbf{R n}$ & Dry & $\mathbf{R n}$ & Dry & $\mathbf{R n}$ & Dry \\
\hline Naphtalene & nd & nd & nd & nd & nd & nd & nd & nd \\
\hline Acénaphtylene & nd & nd & nd & nd & nd & nd & nd & 2.25 \\
\hline Acénaphtene & nd & nd & nd & nd & nd & nd & nd & 3.05 \\
\hline Fluorene & nd & nd & nd & nd & nd & nd & nd & 3.65 \\
\hline Phenanthrene & nd & nd & nd & nd & nd & nd & 8.67 & 19.02 \\
\hline Anthracene & nd & nd & nd & nd & nd & nd & nd & 5.02 \\
\hline$\Sigma$ of (LMW) & nd & nd & nd & nd & nd & nd & 8.67 & 32.99 \\
\hline Fluoranthene & nd & 5.45 & 17.85 & 21.17 & 9.91 & 10.32 & 21.34 & 47.15 \\
\hline Pyrene & nd & 5.64 & 31.58 & 37.20 & 24.57 & 18.42 & 26.34 & 30.61 \\
\hline Benzo[a]anthracene & nd & nd & 7.78 & 4.99 & 7.67 & 9.83 & 12.45 & 16.17 \\
\hline Chrysene & nd & nd & 9.56 & 12.96 & 10.57 & 12.16 & 11.67 & 16.91 \\
\hline Benzo[b]fluoranthene & nd & 4.25 & nd & nd & nd & nd & 3.10 & 4.89 \\
\hline Benzo[k]fluoranthene & nd & 5.02 & nd & nd & nd & nd & 3.75 & 11.51 \\
\hline Benzo[a]pyrene & nd & 5.61 & 14.56 & 36.71 & 9.62 & 22.76 & 12.42 & 27.15 \\
\hline Indeno[1,2,3-cd]pyrene & nd & 11.23 & 39.40 & 56.45 & 16.74 & 15.31 & 24.88 & 17.28 \\
\hline Dibenzo[ah]anthracene & nd & 11.29 & 28.96 & 62.99 & 10.67 & 30.41 & 17.43 & 4.67 \\
\hline Benzo[ghi]perylene & nd & nd & 79.78 & 101.02 & 50.67 & 89.56 & 23.16 & 68.67 \\
\hline$\Sigma$ of $(\mathrm{LMW})$ & nd & 48.89 & 229.47 & 333.49 & 140.42 & 208.77 & 156.54 & 244.86 \\
\hline LMH/LMW & nd & nd & nd & nd & nd & nd & 0.05 & 0.13 \\
\hline UCM & nd & 132.21 & 1984.32 & 2763.23 & 1056.49 & 1563.67 & 1342.11 & 2321.53 \\
\hline$\Sigma$ of 16PAHs & nd & 48.89 & 229.47 & 333.49 & 140.42 & 208.77 & 165.21 & 277.85 \\
\hline
\end{tabular}

Rn: Rainy season; Dry: Dry season; N: Ngoua sediments ; Nd : no detected

LMW / HMW, low molecular weight / high molecular weight; UCM: Unresolved Complex Mixture 


\section{References}

[1] Arias, A., Vazquez-Botello, A., Tombesi, N., Ponce-Vélez, G., Freije, H., Marcovecchio, J., 2010. Presence, distribution, and origins of polycyclic aromatic hydrocarbons (PAHs) in sediments from Bahía Blanca estuary, Argentina. Environmental Monitoring and Assessment 160, 301-314

[2] Asia, L., Mazouz, S., Guiliano, M., Doumenq, P., Mille, G., 2009.'Occurrence and distribution of hydrocarbons in surface sediment from Marseille Bay (France)', Baseline, Marine Pollution Bulletin 58, $424-455$

[3] BAOK Gisèle, (2007) : Pollution des eaux de rivière et les impacts biologiques sur les populations riveraines: cas de la rivière Ngoua dans la zone industrielle de douala bassa (Cameroun), 2007.

[4] Chen, S.J., Luo, X.J., Mai, B.X., Sheng, G.Y., Fu, J.M., Zeng, E., 2006. 'Distribution and mass inventories of polycyclic aromatic hydrocarbons and organochlorine pesticides in sediments of the Pearl River Estuary and the Northern South China Sea' Environmental Science and Technology 40, 709-714

[5] Commendatore M.G., Esteves J.L, Colombo J.C., (2000, 'Hydrocarbons in Coastal Sediments of Patagonia, Argentina: Levels and Probable Sources' Marine Pollution Bulletin, 40 : 989-998 pp

[6] Commendatore, M.G., Esteves, J.L., 2007, 'An assessment of oil pollution in the coastal zone of Patagonia, Argentina' Environmental Management 40, 814-821.

[7] Darilmaz, E., Kucuksezgin, F., 2007 'Distribution and origin of hydrocarbons in surficial sediments from the eastern Aegean Sea (Izmir Bay)' Baseline Marine Pollution Bulletin 54, 1813 1838 .

[8] Doong, R., Lin, Y.T., 2004. 'Characterization and distribution of polycyclic aromatic hydrocarbon contaminations in surface sediment and water from Gao-ping River, Taiwan' Water Research 38, 1733-1744.

[9] Dzalla Ngangue G., (2002): Utilization of soil and dynamique couverture of mangrove in wourri estuary. (Littoral-Cameroon), Master of geographie, $68 \mathrm{p}$.

[10] Gao, X., Chen, S., 2008. 'Petroleum pollution in surface sediments of Daya Bay, South China, revealed by chemical fingerprinting of aliphatic and alicyclic hydrocarbons' Estuarine, Coastal and Shelf Science 80, 95-102.

[11] Guo, W., He, M.C., Yang, Z.F., Lin, C.Y., Quan, X.C., Wang, H.Z., 2007. 'Distribution of polycyclic aromatic hydrocarbons in water, suspended particulate matter and sediment from Daliao River watershed, China' Chemosphere 68, 93-104.

[12] Hellou, J., Steller, S., Zitko, V., Leonard, J., King, T., Milligan, T.G., Yeats, R., 2002. 'Distribution of PACs in surficial sediments and bioavailability to mussels, Mytilus edulis of Halifax Harbour' Marine Environmental Research 53, 357379 .

[13] Khairy, M., Kolba, M., Mostafa, A., EL-Fikyb, A., Bahadira, M., 2009 'Risk assessment of polycyclic aromatic hydrocarbons in a Mediterranean semi-enclosed basin affected by human activities (Abu Qir Bay, Egypt)' Journal of
Hazardous Materials 170, 389 - 397.

[14] Luo, X., Chen, S., Mai, B., Yang, Q., Sheng, G., Fu, J., 2006 'Polycyclic aromatic hydro-carbons in suspended particulate matter and sediments from the Pearl River Estuary and adjacent coastal areas, China' Environmental Pollution 139, 9 - 20.

[15] Massara Paletto, V., Commendatore, M.G., Esteves, J.L., 2008. 'Hydrocarbon levels in sediments and bivalve mollusks from Bahía Nueva (Patagonia, Argentina): an assessment of probable origin and bioaccumulation factors' Baseline/Marine Pollution Bulletin 56, 2082-2105.

[16] Mille, G., Asia, L., Guiliano, M., Malleret, L., Doumenq, P., 2007. 'Hydrocarbons in coastal sediments from the Mediterranean Sea (Gulf of Fos area, France)' Marine Pollution Bulletin 54, 566-575.

[17] Mostafa, A., Wade, T., Sweet, S., Al-Alimi, A., Barakat, A., 2009 ,'Distribution and characteristics of polycyclic aromatic hydrocarbons (PAHs) in sediments of Hadhramout coastal area, Gulf of Aden, Yemen' Journal of Marine Systems 78, 1-8.

[18] Qiu, Y., Zhang, G., Liu, G., Guo, L., Li, X., Wai, O., 2009, 'Polycyclic aromatic hydro-carbons (PAHs) in the water column and sediment core of Deep Bay, South China' Estuarine, Coastal and Shelf Science 83, 60-66.

[19] Rharrassi Filali K., (2008), 'Comporment and caracterization of organic matter in the metalique element traces $(\mathrm{Cu}, \mathrm{Ni}, \mathrm{Pb})$ in the industrial aquifer of Douala-Bassa (Cameroun)'.University of Dschang.

[20] Tolosa, I., Mesa-Albernas, M., Alonso-Hernandez, C., 2009. 'Inputs and sources of hydrocarbons in sediments from Cienfuegos bay, Cuba' Marine Pollution Bulletin 58, 1624-1634.

[21] Volkman, J., Holdsworth, D., Neill, G., Bavor, H., 1992. 'Identification of natural, anthropogenic and petroleum hydrocarbons in aquatic sediments',The Science of the Total Environment 112, 203-219.

[22] Yan, W., Chi, J., Wang, Z., Huang, W., Zhang, G., 2009. 'Spatial and temporal distri-bution of polycyclic aromatic hydrocarbons (PAHs) in sediments from Daya Bay, South China' Environmental Pollution 157, 1823 - 1830.

[23] Yunker, M.B., Macdonald, R.W., Cretney, W.J., Fowler, B.R., McLaughlin, F.A., 1993. 'Alkane, terpene and polycyclic aromatic hydrocarbon geochemistry of the Mackenzie River and Mackenzie shelf: riverine contributions to Beaufort Sea coastal sediment' Geochimica et Cosmochimica Acta 57, 30413061 .

[24] N.Y.M.J. Omar, M.R. Abas, K.A. Ketuly and N. Mohd-Tahir, "Concentrations of PAHs in atmospheric particles (PM-10) and roadside soil particles collected in Kuala Lumpur, Malaysia," Atmospheric Environment 36: 247-254,2002.

[25] L. Chrysikou, P. Gemenetzis, A. Kouras, E. Manoli, E.Terzi and C. Samara, "Distribution of persistent organic pollutants, polycyclic aromatic hydrocarbons and trace elements in soil and vegetation following a large scale landfill fire in northern Greece," Environment International 34: 210 - 225, 2008.

[26] Simoneit B.R.T. 1978. The organic chemistry of marine sediments. In: Riley, J.P. and Chester, R. (eds), Chemical oceanography, Vol. 7, 2nd edition, Academic Press, New York. pp. 233-311. 
[27] Simoneit B.R.T., Sheng G., Chen X., Fu J., Zhang H. and Xu Y. 1991. Molecular marker study of extractable organic matter in aerosols from the urban areas of China. Atmospheric Environment, 25A,2111-2129.

[28] Zhu Y., Liu H., Cheng H., Xi Z., Liu X. and Xu X. 2005. The distribution and source apportionment of aliphatic hydrocarbons in soils from the outskirts of Beijing. Organic Geochemistry. 36, 475-483.
[29] Oyo-lta O.E., Ekpo B.O., Oros D. R. and Simoneit B.R.T. 2010 Distribution and sources of aliphatic hydrocarbons and ketones in surface sediments from the Cross River estuary, S.E. Niger Delta, Nigeria. Journal of Applied Sciences in Environmental Sanitation. 5(1): 13-24. 